\title{
Os antropólogos e a identificação de terras quilombolas no Brasil (1997-2015)'
}

\author{
Anthropologists and the identification of quilombola \\ lands in Brazil (1997-2015)
}

\section{Ana Paula Comin de Carvalho}

Brasil. Universidade Federal do Recôncavo da Bahia (UFRB). Professora associada da Universidade Federal do Recôncavo da Bahia (UFRB). Professora permanente dos Programas de Pós-Graduação em Ciências Sociais da UFRB e de Antropologia da Universidade Federal da Bahia (UFBA). Bolsista de Pós-Doutorado no PPGA/UFF. ID ORCID: https://orcid.org/0000-0003-3457-630X. E-mail: apccarvalho36@yahoo.com.br.

\section{Resumo}

Este artigo tem como tema as práticas e relações entre a antropologia brasileira e a identificação das terras das comunidades remanescentes de quilombos. O direito coletivo a terra para as comunidades negras rurais e urbanas de nosso país não foi baseado num acúmulo de estudos antropológicos sobre essa população, como no caso colombiano. Foi o imaginário sobre o que teriam sido os quilombos que alcançou o estatuto de tema constitucional em 1988. Desse modo, o problema de identificação desses grupos se configurou num campo específico de atuação que envolve uma gama diversificada de mediadores, dentre eles os antropólogos que entre os anos de 1997 e 2015 produziram 209 relatórios de identificação de territórios quilombolas. Diante da inexistência de um balanço sobre esses trabalhos, buscamos preencher essa lacuna a partir da análise de uma amostra desse universo com ênfase nas estratégias de construção de autoridade etnográfica, na política de citações e na narrativa implícita que estruturam os relatórios em questão.

Palavras-chave: Antropologia, Estado, Comunidades Remanescentes de Quilombos.

Artigo elaborado a partir dos dados de minha pesquisa de pós-doutorado sênior, financiada pelo Conselho Nacional de Desenvolvimento Científico e Tecnológico (CNPq), por meio do processo 118306/2017-0, desenvolvida no Programa de Pós-Graduação em Antropologia da Universidade Federal Fluminense, sob a supervisão da professora Eliane Cantarino O’Dwyer.

Recebido em 19 de maio de 2019 


\section{Abstract}

This article has as its theme the practices and relations between the Brazilian anthropology and the identification of the lands of the remaining quilombos communities. The collective right to land for the rural and urban black communities in our country was not based on an accumulation of anthropological studies on this population, as in the Colombian case. It was based on the imaginary concerning what would have been the quilombos which reached the status of constitutional subject in 1988. As such, the matter of identification in these groups focused on a specific field of action involving a diverse range of mediators. Among them are the anthropologists that produced 209 reports of identification for Quilombola territories between the years of 1997 to 2015 . Given the lack of a review about these studies, we sought to fill this gap by analyzing a sample of this universe with emphasis on strategies for building ethnographic authority, on the politics of citations, and on the implicit narrative that structures the reports in question.

Keywords: Anthropology, State, Remaining Communities of Quilombos.

\section{INTRODUÇÃO}

Este artigo discute práticas associadas a demandas por direitos e reconhecimento a partir da relação entre a antropologia brasileira e a identificação de grupos e territórios etnicamente diferenciados, especificamente as comunidades remanescentes de quilombos. Como apontam Lima (2005) e L'Estoile, Neiburg e Sigaud (2002), em geral a participação de antropólogos na elaboração e na implementação de políticas públicas voltadas a tais segmentos tem sido objeto de considerações morais e políticas, mas negligenciada do ponto de vista da análise sociológica. Situações e processos sociais que tradicionalmente foram vistos através das lentes da denúncia e/ou do engajamento no âmbito das antropologias britânica, francesa e norte-americana, recentemente, têm sido examinados de um ponto de vista histórico e comparativo, à luz da história social das ciências sociais, da sociologia do conhecimento científico e da etnografia do estado 
numa perspectiva compreensiva das relações entre os saberes antropológicos e a construção dos estados nacionais (L’ESTOILE; NEIBURG; SIGAUD, 2002).

No caso brasileiro, tal debate já foi sistematizado no que concerne às populações indígenas no livro Antropologia e identificação: os antropólogos e a definição de terras indígenas no Brasil, 1977-2002 (LIMA; BARRETO FILHO, 2005). Um dos aspectos apontados nos capítulos que compõem essa obra e que nos interessa para fins da análise que desenvolvemos - é a mudança de padrão de relatório de identificação de terras indígenas dos trabalhos produzidos no período de 1968-1985, descrita por Antônio Carlos de Souza Lima (2005). Esse padrão seria marcado por um conjunto de articulações discursivas comuns composto por elementos de estilo do realismo etnográfico no sentido proposto por Marcus e Cushman (1982), bem como por uma narrativa, uma organização textual presidida por supostos, ainda que vagos, por meio dos quais se conta sempre a mesma história, a partir do mesmo argumento, operando um script por meio do qual se atua e se improvisa. Nos relatórios do período de 1968-1985, o indígena seria oriundo de um passado idealizado como glorioso, viveria num presente de decadência e desestruturação e teria um futuro sinônimo de assimilação, sendo que caberia à etnografia realizar a reconstituição de uma origem, de uma cultura indígena intocada a fim de descrever essas tradições autênticas antes que elas desaparecessem por completo. Na modificação do padrão de relatório, a história da assimilação teria dado lugar à da resistência, onde agora o conceito-chave seria etnicidade, o passado indígena seria visto como de exploração, o presente como de resistência e o futuro utópico enquanto revivalismo étnico. Além disso, o conceito de "terras tradicionalmente ocupadas" se tornou referência nos relatórios produzido no período de 1986-2003, abandonando-se gradualmente o conceito de "ocupação imemorial” empregado no período anterior (CHAVES, 2005).

No que tange aos relatórios de identificação de terras quilombolas, apesar da importância que essa questão alcançou nos últimos anos e da intensa mobilização de antropólogos para a realização dessas pesquisas, como já observado por Arruti (2006), poucas reflexões de maior fôlego foram desenvolvidas a fim de colaborar para uma maior compreensão desse fenômeno; não obstante a 
importante contribuição da Associação Brasileira de Antropologia (ABA) no debate e na orientação sobre a perícia antropológica voltada para o reconhecimento étnico aplicado à dimensão fundiária ${ }^{2}$, questão que será mais aprofundada em tópico posterior deste artigo. Agora é necessário contextualizar como se configurou a necessidade de elaborar relatórios de identificação de territórios quilombolas.

\section{O ARTIGO 68 DO ATO DAS DISPOSIÇÕES CONSTITUCIONAIS TRANSITÓRIAS, SUAS TENTATIVAS DE REGULAMENTAÇÃO E A PRODUÇÃO DE RELATÓRIOS DE IDENTIFICAÇÃO DE TERRITÓRIOS QUILOMBOLAS}

O direito coletivo a terra para as comunidades negras rurais e urbanas brasileiras remete à Constituição Federal de 1988, em seu Artigo 68, do Ato das Disposições Constitucionais Transitórias (ADCT), que diz: “Aos remanescentes das Comunidades dos Quilombos que estejam ocupando suas terras é reconhecida a propriedade definitiva, devendo o Estado emitir-lhes os respectivos títulos". O contexto mais amplo de emergência desse dispositivo constitucional foi o da "redemocratização" do país, marcado pela retomada dos movimentos camponeses e da campanha pela reforma agrária que requeria, dentre outras coisas, a ampliação das categorias descritivas oficiais sobre a forma de posse e uso da terra para reconhecer aquelas modalidades que não se enquadravam nas já existentes. Esse era o caso das “terras de preto". Estes domínios estariam entregues ou teriam sido adquiridos por famílias de ex-escravos ou antigos escravos com ou sem titulação legal (ALMEIDA, 2002). A construção do direito a terra como um direito humano no caso do Brasil está intimamente vinculada à história recente dos movimentos sociais que lutam pela reforma agrária no país (REIS, 2012). Outrossim, o ano de 1988 foi também dedicado a uma ampla

\footnotetext{
Nesse sentido, cf. O’Dwyer (2002), Leite (2005a), A Carta de Ponta das Canas (2005), o Protocolo de Brasília (ASSOCIAÇÃO BRASILEIRA DE ANTROPOLOGIA, 2015) e Laudos antropológicos em perspectiva (2015), estas três últimas disponíveis para download no site da ABA.
} 
mobilização nacional pelo centenário da abolição da escravatura - marcada por comemorações, marchas, espetáculos, congressos, declarações oficiais e protestos -, agregando grande visibilidade à questão negra no cenário político brasileiro (RIOS, 2012).

Entretanto, diferentemente do caso colombiano, tal conquista não teve como base o acúmulo de estudos antropológicos sobre essa população nesses termos ${ }^{3}$. Conforme apontado por Santos (2015), as comunidades negras brasileiras, especialmente as rurais, ficaram em grande medida à margem do foco das ciências sociais entre o final do século XIX até a segunda metade do século XX. Partindo do pressuposto de que as condições de vida dos negros em situação rural eram culturalmente desagregadoras, o que dificultaria a persistência de cultos, ritos, tradições e poucas ocasiões e espaços de interação entre si, e que no meio urbano haveria melhores condições de persistência de traços culturais africanos e maior potencial de formação de identidades étnicas, muitos pesquisadores privilegiaram o estudo do negro nas cidades, discutindo seus aspectos físicos, culturais e suas formas associativas. Enquanto os sociólogos debatiam a integração e a mobilidade social dos negros no contexto urbano e capitalista, a grande maioria dos antropólogos - caudatários da tradição de estudos afro-brasileiros - vai se dedicar à documentação de aspectos da cultura negra (PINHO, 2008).

A partir dos anos 1960, com a formação dos programas de pós-graduação em antropologia social (PPGAS) no país, as comunidades negras começam a ser alvo de estudos acadêmicos, mas até os anos 1980 eram poucas as obras científicas sobre essa temática. Nos anos 1970, comunidades rurais negras tornaram-se objeto de pesquisas antropológicas sob a chave explicativa do campesinato. Ao final dessa década e início dos anos 1980, os estudos acadêmicos começavam a falar de comunidades negras incrustadas para evitar noções de isolados negros e quilombos, mesmo naqueles casos em que se supunha uma conexão histórica entre essas coletividades e tais agrupamentos. Observa-se aqui uma sutil alteração nas pesquisas que se tornam então estudos sobre comunidades

\footnotetext{
A Lei no 70/1993, sobre os direitos étnicos das comunidades negras da Colômbia, em grande medida foi baseada nos estudos da antropóloga Nina S. de Friedmann sobre os palenques do Pacífico colombiano.
} 
negras rurais ${ }^{4}$. Todavia uma abordagem etnológica e em termos de etnicidade só seria contemplada por um conjunto bastante restrito de trabalhos ao longo da década de 1980 (ARRUTI, 1997, 2000).

O aumento no número de pesquisas sobre essas coletividades só vai acontecer nas décadas de 1990 e 2000, no contexto de ampliação dos PPGAS, criação de normas constitucionais e dispositivos legais, atuação política dos movimentos sociais negros, quilombolas e dos próprios antropólogos, bem como da ressemantização do termo "quilombo" (SILVA, 2015), assunto que trataremos com maiores detalhes mais adiante.

Assim, foi o imaginário sobre o que teriam sido os quilombos - que primeiro ganhou força no campo do movimento social - que alcançou o estatuto de tema constitucional. A apropriação da metáfora dos quilombos pela militância política negra brasileira como ícone da resistência ocorreu no final dos anos 1970 e no início de 1980. Na procura por um vocabulário e paradigma próprios, que lhe permitissem ir além das palavras de ordem do movimento negro norte-americano, o movimento negro brasileiro - estruturado predominantemente em núcleos urbanos - toma os quilombos como sua fonte de inspiração original; associando-os a uma imagem de negros fugidos, caracterizada por sua capacidade de resistência ao assédio da sociedade colonial e pela reprodução de um estilo de vida africano na América (ARRUTI, 2000).

A categoria jurídica escolhida para nomear os novos sujeitos de direitos no processo constituinte brasileiro é extremamente vaga e imprecisa, graças à combinação dos fatores anteriormente elencados com o senso comum e desconhecimento dos congressistas sobre o tema (ARRUTI, 2005). Ela fala em "remanescentes" de uma formação histórica tida como desaparecida com a própria escravidão e que, para ser substituída, teria de ter se mantido invisível diante do Estado. O problema do reconhecimento desses grupos acaba por se configurar num campo específico de atuação que envolve uma gama diversificada de mediadores (militantes dos movimentos sociais negros, políticos,

\footnotetext{
4 Alguns exemplos desses trabalhos são: Brandão (1977), Gusmão (1979), Vogt e Fry (1996), Queiroz (1983), Baiocchi (1987) e Bandeira (1988).
} 
advogados, pesquisadores da antropologia, sociologia, história, arqueologia, dentre outros campos).

Nessa arena, os antropólogos - em especial por meio da ABA - têm uma atuação destacada que rompe com o papel habitualmente desempenhado pelos intelectuais brasileiros nesses contextos. Em vez de garantir com sua autoridade o apoio às reivindicações da sociedade civil por meio de manifestos e documentos, eles têm feito de suas autoridades experienciais um instrumento de reconhecimento público de direitos constitucionais. Desse modo, a participação dos antropólogos nas lutas concorrências que se travam na definição dessa política pública e de Estado, tem se pautado principalmente pelo questionamento ao emprego de formas de reconhecimento estranhas aos próprios atores sociais (como as históricas ou jurídicas, por exemplo) e na ênfase nas definições nativas em que se baseiam as expectativas desses grupos de efetivação da cidadania plena (O'DWYER, 2010).

As demandas sociais geradas pelo Artigo 68 do ADCT implicaram numa atualização teórica do campo disciplinar da antropologia, evidenciando que as questões teóricas também são produzidas socialmente. De acordo com Arruti e Figueiredo (2005), os estudos antropológicos realizados sobre comunidades negras, incrustados ou isolados negros, desde os fins dos anos de 1970, foram retomados após 1988 de forma inteiramente nova. Abandonou-se o referencial teórico-metodológico comum aos primeiros estudos - o conceito de bairro rural - para que fossem adotadas ferramentas conceituais que, acompanhando a formulação dada à questão indígena, já encontravam precedentes na interlocução com o campo jurídico e burocrático estatal, como o conceito de grupo étnico. A adoção do marco teórico da etnicidade não implicou apenas no abandono do naturalismo (raça) ou de um historicismo (os quilombos históricos), mas também na releitura e no reenquadramento dos trabalhos sobre grupos rurais negros do início dos anos 1980 em que predominava a ênfase nas formas culturais (pequenas Áfricas), resultando não somente no rompimento com uma linha de trabalhos acadêmicos, mas com um tipo de discurso político (ARRUTI, 2008).

O conceito de grupo étnico, juntamente com o paradigma histórico e etnológico das terras de uso comum, impõe uma definição de remanescentes 
de quilombos que, rapidamente, foi apropriada como definição operacional. Arruti (2006) realiza uma análise em que mostra de quais campos da pesquisa antropológica advêm os conceitos e as explicações que resultarão nessa definição operacional empregada por antropólogos e movimento desde então: etnologia indígena, campesinato e estudos étnicos. No caso do conceito de reminiscência oriundo do campo de estudos indígenas, para tornar tais grupos nomeáveis, adjetivando-os para que se fizessem visíveis e aceitáveis, uma vez que eram considerados pelo senso comum e mesmo pela academia até então extintos, seja pelo fim do regime escravista, ao qual sua existência se opunha, e sua integração, ainda que subordinada ao trabalho livre no contexto capitalista de relações econômicas e produtivas, ou mesmo pela assimilação física por meio da mestiçagem e simbólica pelo sincretismo da cultura brasileira.

Em relação ao conceito de terras de uso comum, presente sobretudo nos trabalhos de Alfredo Wagner de Almeida (2002, 2010, 2011), observa-se a mesma lógica, ao passo que tais modalidades de territorialidade - tradicionalmente associadas ao campesinato, no interior das quais as terras de preto se inserem enquanto estratégia de autoinvisibilização mediante o caráter repressivo que sempre marcou o emprego das categorias quilombo e mocambo eram consideradas formas atrasadas condenadas ao desaparecimento com a intensificação do capitalismo e sua gradativa e inexorável transformação em mercadoria. O conceito de grupo étnico, derivado das contribuições de Fredrik Barth, vai ser adotado a fim de impor uma definição de remanescentes calcada em critérios subjetivos e contextuais, marcados pelas ideias de contrastividade, oposição e conflito (nesse caso fundiário) a um outro. Seu emprego surge associado a uma afirmação de identidade, que rapidamente se foca na autoatribuição, nos mesmos moldes da identidade indígena.

As ressemantizações antropológicas de quilombo não se limitaram a desfazer um modelo explicativo histórico - que situava o fenômeno num determinado período de tempo e circunscrevia sua expressão a partir de um número limitado e fixo de características (fuga, provisoriedade, isolamento), mas também e simultaneamente propôs outro mais sociológico - que aponta a contemporaneidade do fenômeno a partir da análise da relação entre tais grupos e as categorias jurídicas 
de reconhecimento estatal de sua territorialidade e organização social, das representações coletivas sobre e dos mediadores envolvidos na questão (militantes, pesquisadores, agentes estatais, dentre outros) e que compreende suas características a partir dos contextos sociais, políticos e culturais locais e regionais nos quais tais coletividades estão inseridas. Todavia, ainda que essas ressemantizações tenham se centrado na autoatribuição como forma de escapar ao estereótipo culturalista ou historicista do que tais grupos deveriam ser, sua definição operacional, utilizada tanto por pesquisadores quanto pelo próprio movimento quilombola se revestiu de um caráter descritivo e normativo que dificultava a aceitação de situações que fugissem radicalmente desse modelo. A ampliação de suas margens vinha ocorrendo por meio do acúmulo de reconhecimentos oficiais de comunidades com características relativamente discrepantes da definição original, e não como resultado de uma reflexão teórica sobre seus pressupostos (ARRUTI, 2006; CARVALHO, 2008).

Os impactos das primeiras notícias sobre pleitos de comunidades remanescentes de quilombos urbanas no Rio Grande do Sul e no Rio de Janeiro já tinham me levado a discutir a historicidade e os limites da formulação que transformara esses grupos em sinônimo de comunidades negras rurais ${ }^{5}$. Tentei, na época, demonstrar que a definição operacional era fruto da experiência de pesquisa acumulada até então e que reunia, sob a rubrica do rural, situações extremamente diversas entre si, não podendo ser extensiva a todos os grupos que viessem a se definir como quilombolas (CARVALHO, 2004).

A novidade da questão quilombola acabou por reunir de uma só vez três áreas de estudos até então distintas e independentes no âmbito das ciências sociais: campesinato/rural, raça/etnicidade e sociedades indígenas. Cada uma delas formada por um vocabulário, corpo conceitual e hierarquia de problemas próprios, mas que a partir de então competem sobre tais comunidades. Além disso, produziu uma aliança forçada entre as perspectivas antropológica e histórica até então apartadas, o que resultou na imposição da literatura

\footnotetext{
Me refiro aqui a definição de quilombo proposta pela GT Terras de Quilombo da ABA em 1994: “Toda comunidade negra rural que agrupe descendentes de escravos vivendo da cultura de subsistência e onde as manifestações culturais têm forte vínculo com o passado."
} 
histórica sobre quilombos aos estudos etnográficos sobre comunidades negras rurais e vice-versa (ARRUTI, 1997).

Como já indicado por Lima (2015), precisamos refletir sobre nosso papel - dos antropólogos - quando fazemos Estado, seja como produtores de conhecimento e ideologias, seja no exercício executivo de processos de intervenção. A atuação da ABA em relação à efetivação dos direitos territoriais quilombolas remonta à institucionalização do Grupo de Trabalho Terras de Quilombo, em 1994, e às críticas e sugestões feitas pela Associação em relação às tentativas estatais de implementar e regulamentar o dispositivo constitucional (CARVALHO, 2008).

Desde a promulgação do Artigo 68 do ADCT CF/1988, existiam dúvidas a respeito de se sua aplicação demandava regulamentação complementar. Em 1995, a Fundação Cultural Palmares - FCP (1995) ${ }^{6}$, órgão ligado ao Ministério da Cultura (MinC), emitiu a portaria $n^{\circ} 25$ visando estabelecer normas para os trabalhos de identificação e delimitação das terras ocupadas por comunidades remanescentes de quilombos. No entanto, em novembro desse mesmo ano, o Instituto Nacional de Colonização e Reforma Agrária (Incra) ${ }^{7}$, autarquia do Ministério do Desenvolvimento Agrário (MDA), emitiu a Portaria no 307 , que lhe permitia medir, demarcar e titular as terras quilombolas inseridas em áreas públicas federais (INSTITUTO NACIONAL DE COLONICAÇÃO E REFORMA AGRÁRIA, 1995). Ainda em 1995, o deputado Alcides Modesto e a senadora Benedita da Silva apresentaram projetos de lei sobre o tema. Essas propostas foram analisadas, respectivamente, por Florestan Fernandes e pela

\footnotetext{
6 Órgão criado em 22 de agosto de 1988, possui três departamentos: Departamento de Proteção ao Patrimônio Afro-Brasileiro; Departamento de Fomento e Promoção da Cultura Afro-Brasileira; Centro Nacional de Informação e Referência da Cultura Negra. É no Departamento de Proteção ao Patrimônio Afro-Brasileiro que se encontra a Divisão de Certificação às Comunidades Remanescentes de Quilombos. A FCP conta com representações regionais nos estados de Alagoas, Bahia, Maranhão, Rio de Janeiro e São Paulo.

7 O Incra foi criado em 9 de julho de 1970 com a missão de realizar a reforma agrária e o ordenamento fundiário nacional. A autarquia possui seis diretorias: Programas, Obtenção de Terras e Implantação de Assentamentos, Desenvolvimento de Projetos de Assentamentos, Ordenamento da Estrutura Fundiária, Gestão Administrativa e Gestão Estratégica. A Coordenação Geral de Regularização de Territórios Quilombolas está subordinada à de Ordenamento da Estrutura Fundiária. Possui 30 superintendências regionais e em cada uma delas existe um setor quilombola. Desde 2006, esse setor conta com analistas em reforma e desenvolvimento agrário com habilitação em antropologia.
} 
$\mathrm{ABA}^{8}$. O sociólogo alertava sobre a sobreposição de tarefas entre a FCP e o Incra. A entidade discordava da definição do Incra como órgão responsável pelo processo de regularização fundiária desses territórios, considerada inapropriada uma vez que tais coletividades seriam distintas culturalmente da massa de trabalhadores rurais, o que lhes remeteria ao MinC.

Entre os anos de 1995 a 1998, o Incra expediu seis títulos de terras quilombolas, todos no estado do Pará. A autarquia criou nesse processo de titulações uma rotina administrativa denominada "Projeto Especial Quilombola", que consistia numa adaptação simplificada daquela que já existia no órgão para a criação de assentamentos rurais em áreas públicas federais. De outro lado, a FCP continuava insistindo na criação de condições técnicas para que atender as comunidades remanescentes de quilombos não apenas no plano do mapeamento e da militância cultural e educacional, mas também no de regularização fundiária. A questão que se colocava era se o tema deveria ser trazido para o plano da reforma agrária ou se haveria a necessidade de se fundar um campo institucional novo no interior do Estado, sobre o qual a FCP passaria a ter monopólio nos moldes de uma Fundação Nacional do Índio (Funai). A ABA apoiava a FCP para desenvolver essa tarefa e defendia que caberia a ela a indicação dos peritos aos laudos antropológicos necessários para a aplicação do art. 68 do ADCT 9 .

Entre 1997 e 1999, o Governo Federal produziu propostas de atos e procedimentos necessários para a titulação dos territórios quilombolas reconhecendo a competência da FCP para realizá-los e estabelecendo uma ocupação centenária que remetesse ao período anterior ao fim da escravidão brasileira como critério de caracterização dos remanescentes. Apesar dos protestos das entidades e organizações não governamentais que acompanhavam a questão das comunidades quilombolas e do movimento negro, em outubro de 1999 foi editada a Medida Provisória no 1.911/11 (BRASIL, 1999a), atribuindo ao MinC o cumprimento do art. 68 do ADCT e impedindo o Incra de continuar trabalhando na titulação das áreas quilombolas. Por meio da Portaria no 447

\footnotetext{
8 A correspondência remetida por Florestan Fernandes a Alcides Modesto e a carta da ABA endereçada à senadora Benedita da Silva podem ser encontradas em Silva (1997).

9 O documento da ABA endereçado à FCP em outubro de 1996 expressando esse entendimento pode ser encontrado em Silva (1997).
} 
(BRASIL, 1999b), o MinC delega essa competência à FCP que, por sua vez, pela Portaria no 40 (MINISTÉRIO DA CULTURA, 1999), passou a disciplinar o processo administrativo de reconhecimento de domínio dos territórios quilombolas, que deveria ser composto por um relatório técnico e um parecer conclusivo. Em 10 de setembro de 2001, foi editado o Decreto Presidencial $\mathrm{n}^{\circ}$ 3.912/2001 (BRASIL, 2001), tendo por base os anteprojetos criticados no período de 1997 a 1999 pela sociedade civil. Ele previa que só poderiam ser reconhecidas as propriedades de terras ocupadas por quilombos em 1888 e estavam ocupadas por remanescentes em 5 de outubro de 1988. Juristas, antropólogos e integrantes do movimento negro fizeram inúmeras críticas a esse decreto, em especial pela instituição de uma forma de usucapião especial com prazo de cem anos para os remanescentes (enquanto um cidadão comum precisava comprovar vinte anos de posse mansa e pacífica) e pela adoção do conceito colonial de quilombo.

Em dezembro de 2002, a Coordenação Nacional de Articulação das Comunidades Negras Rurais Quilombolas (Conaq) remeteu ao presidente eleito - Luiz Inácio Lula da Silva - um documento que traçava uma avaliação crítica do desempenho da Fundação Cultural Palmares, sugerindo a revogação do Decreto n 3.912/2001 e que pleiteava a criação de uma Secretaria Nacional de Quilombos no Incra para tratar da questão. No dia 13 de maio instituiu-se um Grupo de Trabalho Interministerial (GT) com a finalidade de rever o Decreto nº 3.912/2001 e propor uma nova regulamentação. Esse GT foi coordenado pela Casa Civil e pela Secretaria Especial de Políticas de Promoção da Igualdade Racial (Seppir), formado por catorze ministérios e três representantes das comunidades quilombolas. Os resultados desse grupo de trabalho foram as minutas dos Decretos $\mathrm{n}^{\circ} 4.883, \mathrm{n}^{\circ} 4.885$ e no 4.887 (BRASIL, 2003a, 2003b, 2003c). O primeiro transferiu a competência para regularizar as terras quilombolas para o Ministério do Desenvolvimento Agrário. O segundo definiu composição, estruturação, competências e funcionamento do Conselho Nacional de Promoção da Igualdade Racial, garantindo aos quilombolas sua participação nesse órgão colegiado de caráter consultivo sobre as políticas de promoção da igualdade racial. O último Decreto regulamentou o procedimento para a identificação, reconhecimento, delimitação, 
demarcação e titulação das terras ocupadas por remanescentes das comunidades dos quilombos. De acordo com ele, compete à Fundação Cultural Palmares inscrever a autodefinição dos grupos em seu Cadastro Geral e expedir uma certidão de autorreconhecimento, bem como ao Incra, titular as áreas quilombolas.

Até essa mudança de competência, a FCP, os Institutos Estaduais de Terras e o Ministério Público Federal ensejaram a produção de relatórios de identificação de territórios quilombolas. Nesse período, a elaboração dos relatórios era guiada pelas normatizações existentes, que não detalhavam seu conteúdo ou o perfil do profissional que deveria realizá-lo. Em alguns casos existiam quesitos formulados pelos demandantes que deveriam ser respondidos.

O Incra elaborou, entre 2004 e 2009, cinco Instruções Normativas (IN) 16/2004, 20/2005, 49/2008, 56/2009 e 57/2009 (INSTITUTO NACIONAL DE COLONIZAÇÃO E REFORMA AGRÁRIA, 2004, 2005, 2008, 2009a, 2009b) a fim de nortear os procedimentos de identificação, reconhecimento, delimitação, desintrusão ${ }^{10}$, demarcação e titulação dos territórios quilombolas.

A primeira mudança normativa - entre as IN 16 e 20 - incluiu o relatório antropológico como uma das peças do Relatório Técnico de Identificação e Delimitação (RTID) dos territórios quilombolas, a ser elaborado pelo órgão. Ele deveria conter informações sobre as terras e edificações destinadas a moradia; as terras para reprodução física, social e cultural do grupo; as fontes terrestres, fluviais, lacustres ou marítimas de subsistência; as terras detentoras de recursos ambientais necessários à preservação de costumes, tradições e lazer; as terras e edificações destinadas a cultos religiosos e os sítios que contivessem reminiscências históricas dos antigos quilombos.

Para que possamos entender por que o relatório antropológico não era um item do RTID desde a primeira normatização do Incra, temos de retroceder à formulação do Decreto n ${ }^{\circ}$ 4.887/2003. Muitos representantes das comunidades dos quilombos que participaram do Grupo de Trabalho Interministerial que elaborou a minuta do referido Decreto entendiam que, na medida em que a caracterização de tais coletividades passaria da comprovação de uma ocupação

\footnotetext{
${ }^{10}$ Palavra que se refere à retirada das famílias não quilombolas do território.
} 
centenária à autodefinição ${ }^{11}$, o relatório antropológico não era necessário e que, se fosse colocado como peça técnica obrigatória, poderia representar um entrave aos processos de regularização fundiária desses grupos. Nesse processo de debate e formulação, a ABA defendia explicitamente a obrigatoriedade dessa peça técnica nos processos de regularização dos territórios quilombolas, alegando sua utilidade em situações de conflito e processos judiciais. Desse modo, ela não só reconhecia a importância do discurso antropológico nas disputas políticas como defendia seu uso na garantia de direitos a segmentos da população historicamente marginalizados ${ }^{12}$.

No dia 25 de junho de 2005, o então Partido da Frente Liberal, atual Democratas, ajuizou uma Ação Direta de Inconstitucionalidade (ADI) sob o $\mathrm{n}^{\circ} 3239$, questionando a legalidade do Decreto $\mathrm{n}^{\circ} 4.887 / 2003 \mathrm{em}$ regulamentar o que estava previsto no art. 68 do ADCT, coisa que só poderia ser feita, a seu ver, por meio de uma lei, a desapropriação de terras produtivas e os critérios de definição dos territórios quilombolas que se pautariam prioritariamente nas indicações dos próprios demandantes. Somam-se a isso os inúmeros recursos administrativos e jurídicos contra os procedimentos de regularização territorial que estavam em curso no Incra e que questionavam a identidade, a historicidade e a territorialidade quilombola. Desse modo, a primeira alteração normativa se deu num contexto de extrema pressão política e jurídica contrária ao reconhecimento desses sujeitos de direitos. Os quilombolas não eram vistos como interlocutores plenamente eficazes para o diálogo com os campos

\footnotetext{
${ }_{11}$ O Decreto $n^{\circ} 3.912 / 2001$, que foi substituído e revogado pelo $n^{\circ} 4.887 / 2003$, previa que: "Somente pode ser reconhecida a propriedade sobre terras que: I - eram ocupadas por quilombos em 1888; e II - estavam ocupadas por remanescentes das comunidades dos quilombos em 5 de outubro de 1988" (BRASIL, 2001, não paginado). O Decreto n 4.887/2003 dispõe que: "Art. $2^{\circ}$ Consideram-se remanescentes das comunidades dos quilombos para fins deste Decreto, os grupos étnico-raciais, segundo critérios de autoatribuição, com trajetória histórica própria, dotados de relações territoriais específicas, com presunção de ancestralidade negra relacionada com a resistência a opressão histórica sofrida. $\$ 1^{\circ}$ Para fins desse Decreto, a caracterização dos remanescentes das comunidades dos quilombos será atestada mediante autodefinição da própria comunidade" (BRASIL, 2003c, não paginado).

${ }^{12}$ Em 16 de outubro de 2003, a ABA enviou ao ministro-chefe da Casa Civil da Presidência da República um ofício em que requeria a inclusão de um artigo no Decreto ${ }^{\circ} 4.887 / 2003$ que definisse a elaboração dos estudos técnicos especializados como responsabilidade do Estado, e não das comunidades, e que tais pesquisas fossem elaboradas por um antropólogo, pois ele seria o especialista, na divisão social do trabalho acadêmico e científico, da questão étnica. O referido ofício foi reproduzido na integra em Leite (2005).
} 
administrativo, político e jurídico, porque lhes faltava legitimidade técnica ou acadêmica que as situações pareciam requerer.

A segunda mudança normativa, entre as IN 20 e 49, redefiniu e detalhou o conteúdo do relatório antropológico. Ele deveria conter introdução, com conceitos e metodologia empregados; dados gerais sobre o município e o grupo; histórico da ocupação; organização social; dados sobre ambiente e produção; e conclusão. Esses seis itens são desdobrados num total de 35 subitens bastante específicos. Estabeleceu-se também que ele deveria ser feito, preferencialmente, por servidores do Incra, vedando a participação de pesquisadores que já tivessem assessorado as comunidades objeto de reconhecimento ${ }^{13}$.

Em 2007 aconteceram grandes mobilizações e articulações contrárias à regularização de territórios quilombolas em vários estados, tais como Espírito Santo e Santa Catarina, liderados pelo Movimento Paz no Campo, que já combatia a reforma agrária. Nessa mesma época foi elaborado um projeto de lei que tinha por objetivo sustar o Decreto $n^{\circ} 4.887 / 2003$. Tais movimentos resultaram na criação de um Grupo de Trabalho formado pela Advocacia-Geral da União (AGU), pelo MDA, pelo Incra e pelo Gabinete de Segurança Institucional (GSI) para elaborar uma nova instrução normativa. A minuta apresentada no fim do ano foi rechaçada tanto pelas comunidades quilombolas quanto pela ABA. Ainda assim, em abril de 2008, uma consulta pública sobre o tema foi realizada junto aos quilombolas e, apesar dos protestos, a IN foi editada algum tempo depois. A terceira mudança normativa, entre as IN 49 e 56, retirava o detalhamento do relatório antropológico, uma vez que isso não cabia a uma instrução normativa, mas a uma norma de execução ou manual. Todavia tal alteração não foi acatada pela AGU e pelo GSI, sob a alegação de que qualquer modificação deveria ser objeto de debate do grupo de trabalho anteriormente formado e de consulta às lideranças quilombolas para sua anuência. Sob pressão interna, a autarquia realiza a quarta e mais recente mudança normativa, entre

\footnotetext{
${ }_{13}$ Cabe esclarecer que a redefinição e o detalhamento foram produzidos num debate de um grupo de trabalho formado por antropólogos indicados pela ABA e pesquisadores que agora compunham o quadro técnico da autarquia desde 2006. No entanto a ideia inicial era de que esses elementos fossem utilizados numa norma de execução ou manual a fim de orientar os profissionais que estariam elaborando ou acompanhando a execução dos relatórios antropológicos, muitos deles recém-formados, com pouca experiência em pesquisa de campo ou com a temática e, agora, integrantes de um órgão estatal.
} 
as IN 56 e 57, o que significou o retorno ao texto original da IN 49. Os antropólogos, inicialmente excluídos das etapas de reconhecimento e delimitação territorial $^{14}$ - como foi no caso da IN 16 - voltam ao campo a partir da IN 20, mas as possibilidades do fazer antropológico, nesses contextos, passam a ser cada vez mais tema de discussão entre os agentes que buscam implementar modificações nas normatizações existentes, com o intuito de objetivar a análise empreendida por esses profissionais, disciplinar o formato de seus estudos e, em última instância, reduzir o tamanho dos territórios reivindicados e os conflitos resultantes dessas demandas.

Desde o ano 2000, a ABA vinha produzido parâmetros para elaborar laudos e relatórios de identificação étnica, territórios tradicionais e de impacto socioambiental. O primeiro deles foi a "Carta de Ponta das Canas" (2005), a fim de balizar a implementação do Acordo de Cooperação Técnica que a Associação havia firmado com a Procuradoria-Geral da República e que previa a indicação de profissionais para produzir esses estudos. Nela recomenda-se que o antropólogo tenha clareza quanto ao fato ou objeto de interesse da justiça ou instituição estatal e apontam-se os quesitos que se espera que sejam respondidos ou atendidos, e se eles foram apresentados de modo que possam ser respondidos adequadamente em termos antropológicos. Além disso, orienta-se para a explicitação dos conceitos, metodologia, técnicas de pesquisa e relevância dos dados apresentados e analisados tendo em vista o diálogo com o campo jurídico e administrativo. O documento também chama atenção para a responsabilidade social e ética do antropólogo para com os grupos que estuda.

Em 2015, num contexto de criação de um curso de especialização para a produção de contralaudos ${ }^{15}$ e da proliferação da modalidade da antropologia de contrato por meio de pregões e licitações públicas para elaborar laudos e relatórios de identificação de áreas indígenas e quilombolas ${ }^{16}$, assim como para

${ }^{14}$ Cabe salientar que, desde 1997, esses relatórios vinham sendo produzidos, especialmente nos casos mais conflitivos, para subsidiar as ações estatais ainda que não existissem quesitos claros por parte das instituições que os demandavam.

15 Tratava-se de uma proposta de curso de especialização para capacitar profissionais para elaborar peças de contestação aos laudos antropológicos de identificação de territórios quilombolas.

${ }^{16}$ Os relatórios de identificação de territórios quilombolas inicialmente eram produzidos a partir de convênios entre os órgãos de governo e as universidades, salvo situações pontuais de contratação de 
mensurar impactos socioambientais a partir de megaprojetos desenvolvimentistas, a ABA formula o Protocolo de Brasília (ASSOCIAÇÃO BRASILEIRA DE ANTROPOLOGIA, 2015). Nele recomenda-se que os antropólogos tenham formação específica (pós-graduação stricto sensu em Antropologia) e experiência de pesquisa com laudos e grupos etnicamente diferenciados (produção acadêmica relevante na área). A graduação em Ciências Sociais e ou Antropologia - critério estabelecido em concursos públicos no MPF, Incra, entre outros órgãos - não é considerada suficiente para atuar na regularização de territórios ou na promoção de direitos diferenciados. Salienta-se a importância da delimitação territorial desses grupos ser pautada por critérios nativos, e não exógenos. Além disso, estabelece-se o prazo mínimo de 120 dias para a elaboração de laudos e perícias. Por fim, ressalta-se a importância de incluir conteúdos curriculares e/ou disciplinas sobre laudos antropológicos na graduação e pós-graduação em Antropologia e Ciências Sociais.

Apesar de contraditórios, outros dois eventos serão extremamente relevantes para a questão: a Comissão Parlamentar de Inquérito (CPI) da Funai e do Incra, e a votação da ADI no 3.239 pelo Supremo Tribunal Federal (STF). Entre 2015 e 2017 duas comissões parlamentares de inquérito foram constituídas para investigar a atuação da Funai e do Incra na demarcação de terras indígenas e de remanescentes de quilombos. No relatório final da última CPI, recomenda-se o indiciamento de 21 antropólogos acusados de parcialidade, ativismo político, falsidade ideológica, dentre outros delitos. Em 8 de fevereiro de 2018, o STF concluiu o julgamento da ADI no 3.239 em relação ao Decreto no 4.887/2003, reafirmando sua constitucionalidade. De um lado, temos a tentativa de criminalização do fazer antropológico e, de outro, a reafirmação do dispositivo legal

profissionais com experiência consolidada na temática, indicados pela ABA. Após o primeiro concurso para antropólogos no Incra em 2005, um número significativo desses trabalhos passou a ser produzido por esses profissionais, muitos deles possuindo apenas a graduação em Ciências Sociais, com habilitação em Antropologia. Vários questionamentos jurídicos quanto aos convênios, em especial devido à participação das fundações universitárias e à remuneração de professores de universidades federais com dedicação exclusiva, levaram o Incra a atender a demanda de produção dos relatórios de duas maneiras: execução interna utilizando antropólogos da própria instituição ou licitação. No contexto das licitações, empresas, geralmente ligadas à elaboração de relatórios de impacto ambiental, passaram a contratar antropólogos para executar lotes, conjunto de relatórios de determinada região de um estado brasileiro. Atualmente, alguns antropólogos têm criado empresas para concorrer nessas licitações. 
que enseja o envolvimento dos antropólogos na produção de relatórios de terras quilombolas. Depois de familiarizar o leitor com esse contexto, abordaremos especificamente os relatórios de identificação de territórios quilombolas.

\section{OS RELATÓRIOS DE IDENTIFICAÇÃO DE TERRITÓRIOS QUILOMBOLAS (1997-2015)}

Os relatórios de identificação de territórios quilombolas já publicados pelo Estado brasileiro, por meio de seus diferentes órgãos e esferas, entre 1997 e 2015, totalizam 209. A maior parte deles foi reunida num acervo digital, graças a uma parceria entre o Incra, o MDA e a Universidade Federal de Minas Gerais (UFMG), e alguns deles foram sintetizados numa linguagem mais acessível na Coleção Terra de Quilombos ${ }^{17}$. Após tratativas com a Coordenação Geral de Regularização de Territórios Quilombolas do Incra, em Brasília, tivemos acesso aos estudos.

A partir da análise desse acervo, elaboramos uma tabela dos relatórios por região, estado, cidade, comunidade, antropólogo responsável e ano de conclusão $^{18}$. A sintetização dessas informações era tarefa imprescindível para conhecer as características mais gerais do universo de relatórios e definir os critérios de composição de sua amostra a ser analisada em profundidade posteriormente. Quando nos debruçamos sobre essas características mais gerais, verificamos que quase metade dos relatórios de identificação de territórios quilombolas se refere a comunidades localizadas na região Nordeste (102 de um total de 209, correspondendo a 48,8\%). Em segundo lugar está região Sudeste, com 40 relatórios, perfazendo 19,1\% do universo. As regiões Norte e Sul têm números absolutos e percentuais bastante próximos (27 e 25 e 12,9\% e 11,9\%, respectivamente). A

\footnotetext{
${ }_{17}$ A Coleção Terra de Quilombos, fruto de uma parceria entre Incra/Comitê Técnico de Povos e Comunidades Tradicionais (CGPCT)/Núcleo de Estudos Agrários e Desenvolvimento Rural (Nead) e UFMG/ Observatório da Justiça no Brasil (OBJ)/Cebras e Núcleo de Estudos em Populações Quilombolas e Tradicionais (NUQ), correspondeu à publicação de 57 livretos, entre os anos de 2015 e 2018, inspirados nos relatórios antropológicos de comunidades remanescentes de quilombos de todas as regiões do país. Disponível em: http://bit.ly/2QKr8Mv. Acesso em: 10 dez. 2019.

${ }_{18}$ Em virtude da sua extensão e das limitações de um artigo, a referida tabela não pode ser incluída aqui como anexo.
} 
região do país com menor número de relatórios produzidos é a Centro-Oeste (15\% e 7,1\%). A distribuição regional dos relatórios segue a mesma ordem das comunidades que se autodefinem enquanto quilombolas perante o Estado brasileiro (certificadas pela FCP). Segundo dados da FCP de 2018, a região Nordeste lidera com 1.788 grupos certificados, seguida pelas regiões Sudeste, com 425, Norte, com 365, Sul, com 176, e Centro-Oeste, com 136.

De acordo com informações do Incra de 2018, a distribuição regional das reivindicações de regularização territorial nesses termos apresenta uma inversão de posições entre as regiões Norte e Sul. A região Nordeste lidera, com 872 procedimentos, seguida pela região Sudeste, com 279, região Sul, com 143, região Norte, com 130 e região Centro-Oeste, com 112. Em termos percentuais, as regiões que têm mais procedimentos abertos de regularização fundiária em relação ao número de comunidades certificadas são: Centro-Oeste, com $82 \%$, Sul, com $81 \%$, Sudeste, com $63 \%$, Nordeste, com $49 \%$, e Norte, com $36 \%$. Entretanto, em muitos casos trata-se apenas do registro formal da reivindicação territorial, sem qualquer ação concreta da autarquia para a titulação. Isso fica ainda mais evidente quando verificamos que, em termos percentuais, as regiões que têm mais relatórios antropológicos publicizados em relação aos procedimentos de regularização fundiária são: Norte, com $21 \%$, Sul, com 17\%, Sudeste, com 14\%, Centro-Oeste, com 13\% e Nordeste, com 12\%.

Contudo, para fins desta pesquisa, mais importante que explicar os fatores que determinam a discrepância entre a autoidentificação dos grupos, sua regularização fundiária e os relatórios antropológicos sobre essas coletividades publicados pelo Estado, foi tentar reproduzir na composição da amostra a ser analisada a mesma tendência de distribuição regional dos estudos etnográficos. Assim, estabelecemos que vinte relatórios comporiam um número representativo do universo existente (209) e que, destes, pelo menos metade deveria ser da região Nordeste, isto é, dez. Outros quatro seriam da região Sudeste, três da região Norte, dois da região Sul e um da região Centro-Oeste.

Outra característica relevante a ser considerada na composição da amostra foi a distribuição normativa dos relatórios, ou seja, o nível de regramento e detalhamento imposto a eles e suas possíveis consequências sobre sua 
forma e seu conteúdo. O maior número de relatórios foi produzido a partir das IN 49 ou 57 do Incra ( $84 \%$ e 40\%, respectivamente) que, como mencionamos anteriormente, esmiuçou as informações requeridas para esse documento por meio de 35 subitens, seguido pela IN 20 (55\% e 26,20\%) que incluiu o relatório como item obrigatório, mas não especificou de maneira pormenorizada o seu conteúdo, pela normatização da FCP (53\% e 25,23\%) e, por fim, pela IN 16 (18\% e 8,57\%), estas duas últimas, como já citado, não exigiam a elaboração de um estudo antropológico, mas de informações diversas sobre tais grupos que poderiam ser fornecidas por outros tipos de profissionais. Levando isso em consideração, definimos que oito relatórios selecionados para uma análise mais aprofundada deveriam ter sido produzidos sob as IN 49 ou 57, cinco sob a IN 20, cinco sob a normatização da FCP e dois sob a IN 16.

Na composição da amostra, também consideramos o fato de que eles foram produzidos por profissionais com ou sem vinculação a instituições de ensino e experiência prévia de pesquisa na temática, por demanda interna ou externa aos órgãos estatais e por instrumentos jurídicos diversos (convênio, contrato, licitação, cooperação). Seguindo todos critérios elencados anteriormente, chegamos à composição conforme apresentado no Quadro 1.

QUADRO 1 - AMOSTRA DE RELATÓRIOS.

\begin{tabular}{|c|c|c|}
\hline Região: & Comunidade/Estado & Normatização \\
\hline \multirow{10}{*}{ Nordeste (10) } & 1 - Brejão dos Negros/SE & IN Incra 49 ou 57 \\
\hline & $2-$ Caraíbas/SE & IN Incra 49 ou 57 \\
\hline & 3 - Pontal da Barra/SE & IN Incra 49 ou 57 \\
\hline & 4-Mocambo/SE & FCP \\
\hline & 5- Mangal, Barro Vermelho/BA & IN Incra 49 \\
\hline & $\begin{array}{l}\text { 6- Lagoa do Ramo e } \\
\text { Goiabeira/CE } \\
\end{array}$ & IN Incra 20 \\
\hline & $\begin{array}{l}7 \text { - São Francisco Malaquias/ } \\
\text { MA }\end{array}$ & IN Incra 20 \\
\hline & $\begin{array}{l}\text { 8-Território quilombola do } \\
\text { Guaí/BA }\end{array}$ & IN Incra 20 e 49 \\
\hline & 9 - Caonge/BA & IN Incra 49 ou 57 \\
\hline & 10 - Jetimana e Boa Vista/BA & IN Incra 49 ou 57 \\
\hline
\end{tabular}




\begin{tabular}{|c|c|c|}
\hline Região: & Comunidade/Estado & Normatização \\
\hline \multirow{4}{*}{ Sudeste (4) } & 11 - Ivaporunduva/SP & $\begin{array}{l}\text { Instituto de Terras do Estados } \\
\text { de São Paulo (Itesp)/MPF/FCP }\end{array}$ \\
\hline & 12 - Marambaia/RJ & $\mathrm{FCP}$ \\
\hline & 13 - Cabral/RJ & IN Incra 20 \\
\hline & $14-$ Gurutuba/MG & FCP e IN Incra 16 \\
\hline \multirow{3}{*}{ Norte (3) } & $\begin{array}{l}\text { 15 - São Raimundo do Pirativa/ } \\
\text { AP }\end{array}$ & IN Incra 49 ou 57 \\
\hline & 16 - Santa Luzia/PA & IN Incra 49 ou 57 \\
\hline & 17 - Kalunga do Mimoso/TO & IN Incra 16 \\
\hline \multirow{2}{*}{ Sul (2) } & $18-$ Casca/RS & FCP e IN Incra 16 \\
\hline & 19 - Rincão dos Martimianos/RS & FCP \\
\hline Centro-Oeste (1) & 20 - Chácara dos Buritis/MS & IN Incra 20 \\
\hline
\end{tabular}

A questão mais geral que buscamos responder na análise desse conjunto de trabalhos é se seria possível verificar um padrão de relatório de identificação de terras quilombolas nos estudos produzidos no período, padrão esse que seria marcado por um conjunto de articulações discursivas comuns. Em outras palavras, se haveria um gênero de documento com um padrão discursivo característico, isto é, com um apanhado de conceitos e estratégias retóricas e textuais reiteradamente utilizados.

O objetivo geral desta pesquisa se desdobrou em dois objetivos específicos. O primeiro se refere às formas e aos dispositivos de construção de autoridade etnográfica e produção de convencimento empregadas, inspirando-se nas contribuições de Clifford (2011), Gonçalves (2011), Crapanzano (2016) e Latour (2000). A noção de autoridade é usada para pensar as estratégias retóricas pelas quais os antropólogos, enquanto autores, constroem sua presença no texto, assegurando, em termos epistemológicos e políticos, a legitimidade do seu discurso sobre aquele contexto social e cultural a ser representado. Em outras palavras, o conjunto de artifícios discursivos utilizados pelo antropólogo para convencer o leitor de que deve acreditar em seu relato (COELHO, 2016). A autoridade etnográfica é tomada como peça fundamental na própria constituição do texto etnográfico, ao mesmo tempo em que é de suma importância na articulação da experiência apresentada. 
Ela é o próprio conhecimento etnográfico que é constituído por distintas estratégias de autoridade (GONÇALVES, 2011).

Como aponta Clifford (2011), o processo de escrita etnográfico é complicado pela ação de múltiplas subjetividades e constrangimentos políticos que estão acima do controle do escritor. Penso que isso seja ainda mais intenso no caso dos relatórios de identificação de territórios quilombolas, uma vez que nesse contexto temos o embaralhamento de posições e ideias costumeiramente associadas a uma experiência etnográfica tradicional. Em resposta a essas forças, a escrita etnográfica performatiza uma estratégia específica de autoridade.

Clifford (2011) cria quatro tipos ideais de autoridade etnográfica: experiencial, interpretativa, dialógica e polifônica. Enquanto tipos ideais, nos termos weberianos, não seriam encontrados de forma pura nos textos etnográficos, ainda que seja possível apontar autores e obras que seriam exponenciais ou exemplares de cada modalidade.

Nas etnografias clássicas, há uma afirmação não questionada, de modo a aparecer como provedora da verdade no texto. Os trobriandeses são assim, os nuer pensam desse modo, afirmações essas que se legitimam pelo fato de o pesquisador ter estado lá por um longo período e ter obtido esses dados a partir de um convívio próximo com os nativos por meio da observação participante. Trata-se da autoridade experiencial, em que a experiência do pesquisador serve como fonte unificadora de autoridade no campo. Ela se baseia numa "sensibilidade" do pesquisador para o contexto nativo, uma espécie de conhecimento tácito acumulado e certo sentido agudo em relação ao estilo de determinado povo e de um lugar. Uma narrativa bem-definida surge aqui - a de um estranho entrando em uma cultura, sofrendo uma iniciação que levaria a algum tipo de aceitação e empatia mínimos. Resulta dessa experiência um texto representacional escrito pelo observador participante. Os apelos a experiência funcionam muitas vezes como validações para a autoridade etnográfica.

De acordo com Coelho (2016), Geertz, em seu livro Obras e idas: o antropólogo como autor, propõe que a estratégia-síntese de construção da autoridade etnográfica seria o "estar lá". Essa estratégia se desenvolveria em duas etapas no texto. Na primeira, o etnógrafo estabelece que esteve lá no campo 
que agora descreve por meio de um minucioso relato inicial com descrições detalhadas do lugar. Na segunda, ele desaparece do texto, produzindo no leitor uma impressão de objetividade, como se qualquer um que estivera lá como ele tivesse visto exatamente o que ele viu.

Vicente Crapanzano (2016) também aponta como elementos empregados na constituição da autoridade etnográfica: a presença do etnógrafo nos eventos descritos, sua capacidade de percepção, sua perspectiva "desinteressada", sua objetividade e sinceridade.

A autoridade interpretativa surge como uma alternativa à autoridade experiencial. Ela é gerada a partir da afirmação de que se estão representando mundos diferentes e significativos. A etnografia é a interpretação das culturas, tomadas enquanto textos, ou mais bem apropriadas apenas por meio de formas textualizadas. Essas formas textualizadas se tornam evidências de um contexto englobante, uma realidade cultural. Autores e atores específicos são separados de suas produções e um autor generalizado precisa ser criado para responder ao mundo ou contexto dentro do qual esses textos são ficcionalmente realocados. Esse autor generalizado aparece sob uma infinidade de nomes: o ponto de vista nativo, os balineses, os dogon etc. O etnógrafo, assim como o crítico literário, tem a tarefa de organizar os significados não controlados em um texto numa única intenção coerente. Ele transforma as ambiguidades e diversidades de significado da situação de pesquisa num retrato integrado. A virtuosidade interpretativa seria uma forma de estabelecer diretamente a validade das interpretações etnográficas - uma análise exemplar, a qualidade exemplar ajudaria a torná-la etnograficamente convincente (CRAPANZANO, 2016). Os aspectos dialógicos, situacionais da interpretação etnográfica, são banidos para outros lócus textuais. O relato do trabalho de campo é feito em separado, geralmente no início dos textos, tornando mais difícil ao leitor perceber que parte essencial da construção dessa interpretação é dialógica, e não a leitura da cultura por cima dos ombros dos nativos.

$\mathrm{Na}$ amostra de relatórios, o trabalho de campo é, muitas vezes, pouco detalhado e tem sido reduzido drasticamente nos últimos anos (de oito a seis meses para trinta dias). Essa redução está diretamente relacionada com a forma 
de contratação dos estudos, uma vez que, nos convênios com universidades e fundações universitárias, esse tempo era determinado pelos próprios pesquisadores, enquanto nos contratos por pregão existe um número mínimo de dias predeterminado no edital do certame que as empresas evitam estender para diminuir os custos e maximizar o lucro. Na parte introdutória dos relatórios se estabelece que o etnógrafo esteve em campo, ainda que a intensidade e duração dessa estadia não seja pormenorizada na escrita. Nos demais capítulos, observa-se uma tendência de desaparecimento do pesquisador do texto, seja pela adoção de um sujeito e tempo verbal impessoal, seja pela minimização de sua presença e intervenção, por meio da supressão do seu nome nas transcrições de entrevistas, ou pelo uso de siglas ou da denominação do entrevistador. Isso que nos leva a crer que, na maioria dos casos, a autoridade etnográfica não se produz nos relatórios de modo experiencial, mas interpretativo.

O uso de categorias genéricas de referência (os membros da comunidade, os quilombolas, as mulheres quilombolas, os jovens quilombolas etc.) que visam unificar o discurso e criar autor/atores genéricos e de histórias exemplares de relações de parentesco, expropriação territorial, racismo, entre outros, são outros indicadores da tentativa de construção de uma autoridade etnográfica interpretativa nesses textos.

Em vários relatórios há uma defesa explícita do papel do antropólogo como intérprete, tradutor de sentidos, significados, das aspirações e noções particulares de justiça na construção de um pleito territorial, o que nos remete novamente à autoridade de cunho interpretativo. Em algumas passagens dos textos podemos vislumbrar interpretações processuais dos autores que tentam ultrapassar a visão nativa naturalizada das dinâmicas sociais, o que evidencia o papel do antropólogo na representação de realidades diferentes e significativas.

É possível identificar pelo menos dois tipos de relatórios: descritivos, com menos teoria e conceitos, que foram mais recorrentes no período em que sua produção ficou sob a responsabilidade e normatização da FCP (até março de 2004); e analíticos, com mais teoria e conceitos, que se tornaram predominantes a partir da IN 20 do Incra (a partir de maio de 2005). Entretanto também 
verificamos mais recentemente o uso de categorias operacionais em detrimento de um marco teórico mais consistente nos textos. Isso pode estar relacionado com o acúmulo de experiências dos próprios autores sobre o tema e a familiarização dos agentes estatais com os conceitos e categorias, de tal modo que sua problematização e explicitação não se coloque mais como uma questão a ser equacionada textualmente.

$\mathrm{Na}$ análise da amostra dos relatórios, um dos elementos de destaque é a importância da interlocução com a historiografia na construção dos textos etnográficos, seja para contestar a representação construída sobre as comunidades remanescentes de quilombos, para lamentar a ausência de produção sobre o tema na região em questão ou, ainda, para interrogar essa produção em outros termos, buscando, a partir da perspectiva antropológica, revelar o que ela intencionalmente ou não contribuiu para a invisibilização. Nesse sentido, caberia à etnografia não apenas descrever, mas em larga medida contribuir para configurar a existência desses grupos sob novos termos. Todavia a relação com a história a partir da memória coletiva dos grupos é uma das questões mais problemáticas dos relatórios, visto que a história oral e as fontes tradicionais são duas formas de acesso à memória que encerram contradições, nos permitindo vislumbrar narrativas que podem ser justapostas, mas nem sempre conciliadas num todo coerente (ARRUTI, 2005).

A apresentação de genealogias, fotos e documentos intercalados com e/ ou ao fim dos elementos textuais é outro aspecto relevante que, de um lado, aponta para temáticas tradicionais da antropologia (como os estudos de parentesco e organização social), proeminentes (antropologia visual) e/ou mais contemporâneas (etnografia de documentos) que estão presentes nos relatórios e, de outro, nos remete para o tipo de leitor para quem esses textos estão sendo produzidos (no âmbito administrativo e, muitas vezes, no jurídico) e o tipo de interlocução possível, ou mais eficaz (a retórica da prova, da valorização dos documentos e registros textuais e visuais nesse contexto). Nesse mesmo sentido, as longas transcrições de trechos de entrevistas presentes nos relatórios apontam para a importância do testemunho na produção de convencimento do leitor. 
Bruno Latour (2000), em seu livro Ciência em ação: como seguir cientistas e engenheiros sociedade afora, aborda as táticas empregadas pelos cientistas na construção dos seus textos no que se refere à política de citações. Artigos mais antigos são citados para demonstrar ao leitor a inserção do autor na disciplina, enquanto artigos mais recentes atestam a atualidade da sua pesquisa. $\mathrm{O}$ texto se fortalece à medida que vão se lançando mais referências. Essas ações visam inibir o leitor a discordar do que o texto diz, na medida em que, ao fazê-lo, não se estaria discordando apenas do autor, mas de toda a bibliografia sobre o tema que ele cita. Guardadas as devidas proporções, entendo que a política de citações presente nos relatórios de identificação de territórios quilombolas seja uma estratégia de construção de autoridade etnográfica e de convencimento dos leitores que se soma àquelas anteriormente mencionadas.

Em relação à política das citações, destacam-se os seguintes conceitos e autores nos relatórios da amostra: grupos étnicos e etnicidade (BARTH, 1969; OLIVEIRA, 1976); quilombos contemporâneos (ALMEIDA, 2010; ARRUTI, 1997; LEITEb, 2005; O'DWYER, 2002;); terras de uso comum e terras tradicionalmente ocupadas (ALMEIDA, 2010); processo de territorialização (OLIVEIRA, 1998), territorialidade (LITLLE, 2003), mas também referências da geografia, campesinato (HEREDIA, 1979; MOURA, 1988; QUEIROZ, 1983; WOORTMANN, 1985; WOORTMANN, 1990;), memória (GODOI, 1999; HALBWACS, 2013; POLLAK, 1992). Evidencia-se uma prevalência de referências nacionais, muitas das quais já escreveram relatórios de identificação de território indígena e/ou quilombola e têm trajetória de pesquisa consolidada sobre o tema, reconhecida dentro e fora do campo acadêmico. Outrossim também é possível vislumbrar as tradições de estudos antropológicos em relação às quais se filiam a maior parte dos autores dos relatórios: etnologia indígena, estudos afro-brasileiros e campesinato.

O segundo objetivo específico dessa pesquisa diz respeito ao subtexto que informa e conduz a elaboração do texto. Nesse sentido, interessa-nos saber se essas etnografias são guiadas por uma estrutura narrativa implícita, ou seja, por uma estória nos termos de Edward Bruner (1986), e quais os termos-chave e conceitos que a caracterizariam. $\mathrm{O}$ autor identifica duas narrativas, estórias, a 
da assimilação e a da resistência dos nativos norte-americanos, que teria servido de guia para ordenar a experiência de campo dos etnógrafos com essas populações em dois períodos - de 1930/40 a 1970 e de 1970 em diante. Essas narrativas seriam simultaneamente estruturas de significação e poder, assim como não teriam apenas caráter interpretativo, mas também estruturante, na medida em que produziriam arquétipos - o do índio exótico ou da vítima do homem branco - que seriam compartilhados por índios e brancos, dentre eles os antropólogos. Enquanto na primeira narrativa assimilação seria o próprio termo-chave, na segunda o principal conceito seria etnicidade. Creio ser possível e extremamente interessante estabelecer um paralelo no que a tange à produção de estudos antropológicos sobre comunidades negras rurais e urbanas, especialmente a partir dos relatórios de identificação de terras quilombolas.

No que diz respeito à narrativa implícita que estrutura os relatórios, temos a ideia de que as comunidades quilombolas resistiram e resistem à integração ao contexto capitalista, principalmente por meio de sua territorialidade. A constituição de territórios ou campos negros são tomadas nos textos etnográficos como expressões de resistência desses grupos. A luta pela manutenção dessa territorialidade se expressa contemporaneamente em termos étnicos negando a narrativa dominante no âmbito das ciências sociais e da sociedade brasileira a partir dos anos 1950, que pregava a integração, ainda que subordinada, do negro à sociedade de classes e que presumia sua integração física via mestiçagem e cultural via sincretismo. Tidos até então como em "desaparecimento" ou "assimilados" pela sociedade nacional, esses novos sujeitos políticos passam a colocar em dúvida o próprio discurso da nação, isto é, o mito da democracia racial (LEITE, 2005a).

\section{CONSIDERAÇÕES FINAIS}

Desde o início dos anos 1990, os antropólogos brasileiros têm contribuído para a produção de um conjunto diversificado e valioso de reflexões sobre inúmeros aspectos da questão quilombola em termos teóricos, metodológicos 
e empíricos. Seja por intermédio da ABA e do Grupo de Trabalho Terras de Quilombos, ou por grupos de pesquisa e pesquisadores isolados articulados a universidades e/ou organizações não governamentais, em temas como: o conceito de quilombo (ALMEIDA, 2011; O'DWYER, 2002), conflitos territoriais (ALMEIDA, 2010; OLIVEIRA, 2016; OLIVEIRA, 2016), os quilombos e a prática profissional dos antropólogos (LEITE, 2005a; NÚCLEO DE ESTUDOS SOBRE IDENTIDADE E RELAÇÕES INTERÉTNICAS, 2006; O'DWYER, 2002;); e procedimentos de titulação (NÚCLEO DE ESTUDOS SOBRE IDENTIDADE E RELAÇÕES INTERÉTNICAS, 2005). Entretanto, via de regra, o foco são as experiências particulares dos pesquisadores na condução de um relatório específico.

Assim, esta análise é uma primeira tentativa de refletir sobre a produção de relatórios de identificação de territórios quilombolas em termos mais globais. Por isso não temos a pretensão de apresentar considerações definitivas, mas, sim, apontar aspectos que merecem maior reflexão de nossa parte quando tratamos do fazer antropológico atual associado a demandas por direito e reconhecimento. De toda sorte, entendemos que o debate suscitado por este artigo nos permite compreender melhor alguns aspectos do desenvolvimento da Antropologia no Brasil no que se refere à produção de conhecimento sobre a população afro-brasileira e da conformação das políticas afirmativas no país.

\section{REFERÊNCIAS BIBLIOGRÁFICAS}

1. A CARTA de Ponta das Canas. In: LEITE, Ilka Boaventura (org.). Laudos periciais antropológicos em debate. Florianópolis: ABA, 2005. p. 34-43.

2. ALMEIDA, Alfredo Wagner Berno de. Os quilombos e as novas etnias. In: O'DWYER, Eliane Cantarino (org.). Quilombos: identidade étnica e territorialidade. Rio de Janeiro: Editora FGV, 2002.

3. ALMEIDA, Alfredo Wagner Berno de. Nova cartografia social: territórios quilombolas e conflitos. Manaus: UEA Edições, 2010.

4. ALMEIDA, Alfredo Wagner Berno de. Quilombos e as novas etnias. Manaus: UEA Edições, 2011. 
5. ARRUTI, José Maurício Andion. A emergência dos “remanescentes": notas para o diálogo entre indígenas e quilombolas. Mana, Rio de Janeiro, v. 3, n. 2, p. 7-38, 1997.

6. ARRUTI, José Maurício Andion. Direitos étnicos no Brasil e na Colômbia: notas comparativas sobre hibridação, segmentação e mobilização política de índios e negros. Horizontes Antropológicos, Porto Alegre, ano 6, n. 14, p. 93-123, 2000.

7. ARRUTI, José Maurício Andion. Etnografia e história do Mocambo: notas sobre uma "situação de perícia". In: LEITE, Ilka Boaventura (org.). Laudos periciais antropológicos em debate. Florianópolis: Nuer, 2005.

8. ARRUTI, José Maurício Andion. Mocambo: antropologia e história do processo de formação quilombola. Bauru: Edusc, 2006.

9. ARRUTI, José Maurício Andion. Relatório antropológico de reconhecimento territorial da comunidade quilombola de Cabral: município de Parati-RJ. Rio de Janeiro: Incra, 2008.

10. ARRUTI, José Maurício Andion; FIGUEIREDO, André. Processos cruzados: configuração da questão quilombola e campo jurídico no Rio de Janeiro. In: NÚCLEO DE ESTUDOS DE IDENTIDADESE RELAÇÕES INTERÉTNICAS. Territórios quilombolas: reconhecimento e titulação das terras. Florianópolis: Nuer, 2005. p. 73-93. (Boletim Informativo do Nuer v. 2, n. 2).

11. ASSOCIAÇÃO BRASILEIRA DE ANTROPOLOGIA. Protocolo de Brasília. Laudos antropológicos: condições para o exercício de um trabalho científico. Rio de Janeiro: ABA, 2015.

12. BAIOCCHI, Mari de Nasaré. Negros de Cedro: um estudo antropológico de um bairro rural de Goiás. São Paulo: Ática, 1987.

13. BANDEIRA, Maria de Lourdes. Território negro em espaço branco: estudo antropológico de Vila Bela. São Paulo: Brasiliense, 1988.

14. BARTH, Fredrik (org.). Ethnic groups and boundaries. London: George Allen \& Unwin, 1969.

15. BRANDÃO, Carlos Rodrigues. Peões, pretos e congos: trabalho e identidade étnica em Goiás. Brasília, DF: Editora UnB, 1977.

16. BRASIL. Medida provisória no 1.911-11, de 26 de outubro de 1999. Altera dispositivos da Lei no 9.649, de 27 de maio de 1998, que dispõe sobre a organização da Presidência da República e dos Ministérios, e dá outras providências. Brasília, DF, 1999a. Disponível em: http://bit.ly/2FknWJs. Acesso em: 29 set. 2015.

17. BRASIL. Portaria $n^{\circ} 447$, de 2 de dezembro de 1999. Delega competência à titular da Presidência da Fundação Cultural Palmares. Brasília, DF: Ministério da Cultura, 1999b. 
18. BRASIL. Decreto $\mathbf{n}^{\circ}$ 3.912, de 10 de setembro de 2001. Regulamenta as disposições relativas ao processo administrativo para identificação dos remanescentes das comunidades dos quilombos e para o reconhecimento, a delimitação, a demarcação, a titulação e o registro imobiliário das terras por eles ocupadas. Brasília, DF, 2001. Disponível em: http://bit.ly/2SSBhki. Acesso em: 29 set. 2015.

19. BRASIL. Decreto $\mathbf{n}^{\mathbf{0}} \mathbf{4 . 8 8 3}$, de 20 de novembro de 2003. Transfere a competência que menciona, referida na Lei $n^{\circ} 10.683$, de 28 de maio de 2003, que dispõe sobre a organização da Presidência da República e dos Ministérios, e dá outras providências. Brasília, DF, 2003a. Disponível em: http://bit.ly/2SWMSPv. Acesso em: 29 set. 2015 .

20. BRASIL. Decreto $\mathrm{n}^{\circ} \mathbf{4 . 8 8 5}$, de 20 de novembro de 2003. Dispõe sobre a composição, estruturação, competências e funcionamento do Conselho Nacional de Promoção da Igualdade Racial - CNPIR, e dá outras providências. Brasília, DF, 2003b. Disponível em: http://bit.ly/2QLY3aH. Acesso em: 29 set. 2015.

21. BRASIL. Decreto $n^{\circ} \mathbf{4} .887$, de 20 de novembro de 2003. Regulamenta o procedimento para identificação, reconhecimento, delimitação, demarcação e titulação das terras ocupadas por remanescentes das comunidades dos quilombos de que trata o art. 68 do Ato das Disposições Constitucionais Transitórias. Brasília, DF, 2003c. Disponível em: http://bit.ly/35t1AQD. Acesso em: 29 set. 2015.

22. BRUNER, Edward. Ethnography as narrative. In: Turner, Victor. The Anthropology of experience. Chicago: University of Illinois Press, 1986.

23. CARVAlHO, Ana Paula Comin de. O "Planeta" dos negros no mundo dos brancos: estudo sobre a manutenção e atualização das fronteiras étnicas de uma comunidade negra na cidade de Canoas/RS. 2004. Dissertação (Mestrado em Antropologia Social) - Instituto de Filosofia e Ciências Humanas, Universidade Federal do Rio Grande do Sul, Porto Alegre, 2004.

24. CARVAlHO, Ana Paula Comin de. O espaço da diferença no Brasil: etnografia de políticas públicas de reconhecimento territorial e cultural negro no Sul do país. 2008. Tese (Doutorado em Antropologia Social) - Instituto de Filosofia e Ciências Humanas, Universidade Federal do Rio Grande do Sul, Porto Alegre, 2008.

25. CHAVES, Rodrigo Pádua Rodrigues. A identificação de terras indígenas e os relatórios de identificação e delimitação da Funai: reflexões sobre a prática da antropologia no Brasil (1988-2003). In: LIMA, Antonio Carlos de Souza Lima; BARRETO FILHO, Henyo Trindade (org.). Antropologia e identificação: os antropólogos e a definição de terras indígenas no Brasil, 1977-2002. Rio de Janeiro: Contra Capa, 2005.

26. CLIFFORD, James. A experiência etnográfica: antropologia e literatura no século XX. Rio de Janeiro: Editora da UFRJ, 2011. 
27. COELHO, Maria Claudia. Sobre tropas e cornetas: apresentação a edição brasileira de Writing Culture. In: CLIFFORD, James; MARCUS, George. A escritura da cultura: poética e política da etnografia. Rio de Janeiro: EdUERJ, 2016.

28. CRAPANZANO, Vicent. O dilema de Hermes: o disfarce da subversão na descrição etnográfica. In: CLIFFORD, James; MARCUS, George. A escritura da cultura: poética e política da etnografia. Rio de Janeiro: EdUERJ, 2016.

29. FUNDAÇÃO CULTURAL PALMARES. Portaria nº 25, de 15 de agosto de 1995. Diário Oficial da União, Brasília, DF, 22 ago. 1995. Seção 1, p. 12827-12828.

30. GODOI, Emilia Pietrafesa de. O trabalho da memória: cotidiano e história no sertão do Piauí. Campinas: Editora da Unicamp, 1999.

31. GONÇALVES, José Reginaldo Santos. Apresentação. In: CLIFFORD, James. A experiência etnográfica: antropologia e literatura no século XX. Rio de Janeiro: Editora da UFRJ, 2011.

32. GUSMÃO, Neusa. Campinho da independência: um caso de proletarização Caiçara. 1979. Dissertação (Mestrado em Antropologia) - Pontifícia Universidade Católica de São Paulo, São Paulo, 1979.

33. HALBWACHS, Maurice. A memória coletiva. Tradução de Beatriz Sidou. 2. ed. São Paulo: Centauro, 2013.

34. HEREDIA, Beatriz. A morada da vida: trabalho familiar entre pequenos produtores do Nordeste do Brasil. Rio de Janeiro: Paz \& Terra, 1979.

35. INSTITUTO NACIONAL DE COLONIZAÇÃO E REFORMA AGRÁRIA. Portaria no 307, de 22 de novembro de 1995. Brasília, DF, 1995. Disponível em: http://bit.ly/2sAwGIY. Acesso em: 29 set. 2015.

36. INSTITUTO NACIONAL DE COLONIZAÇÃO E REFORMA AGRÁRIA. Instrução Normativa $n^{\circ} 16$, de 24 de março de 2004 . Regulamenta o procedimento para identificação, reconhecimento, delimitação, demarcação e titulação das terras ocupadas por remanescentes das comunidades dos quilombos de que trata o art. 68 do Ato das Disposições Constitucionais Transitórias. Brasília, DF, 2004. Disponível em: http://bit.ly/2QmJOuk. Acesso em: 29 set. 2015.

37. INSTITUTO NACIONAL DE COLONIZAÇÃO E REFORMA AGRÁRIA. Instrução Normativa no 20, de 19 de setembro de 2005. Regulamenta o procedimento para identificação, reconhecimento, delimitação, demarcação, desintrusão, titulação e registro das terras ocupadas por remanescentes das comunidades dos quilombos de que tratam o Art. 68 do Ato das Disposições Constitucionais Transitórias da Constituição Federal de 1988 e o Decreto n 4.887, de 20 de novembro de 2003. Brasília, DF, 2005. Disponível em: http:// bit.ly/2QkviTM. Acesso em: 29 set. 2015. 
38. INSTITUTO NACIONAL DE COLONIZAÇÃO E REFORMA AGRÁRIA. Instrução Normativa $n^{\circ} 49$, de 29 de setembro de 2008. Regulamenta o procedimento para identificação, reconhecimento, delimitação, demarcação, desintrusão, titulação e registro das terras ocupadas por remanescentes das comunidades dos quilombos de que tratam o Art. 68 do Ato das Disposições Constitucionais Transitórias da Constituição Federal de 1988 e o Decreto n ${ }^{\circ}$ 4.887, de 20 de novembro de 2003. Brasília, DF, 2008. Disponível em: http://bit. ly/35kJ2Ci. Acesso em: 29 set. 2015.

39. INSTITUTO NACIONAL DE COLONIZAÇÃO E REFORMA AGRÁRIA. Instrução Normativa $n^{\circ} 56$, de 7 de outubro de 2009. Regulamenta o procedimento para identificação, reconhecimento, delimitação, demarcação, desintrusão, titulação e registro das terras ocupadas por remanescentes das comunidades dos quilombos de que tratam o Art. 68 do Ato das Disposições Constitucionais Transitórias da Constituição Federal de 1988 e o Decreto no 4.887, de 20 de novembro de 2003. Brasília, DF, 2009a. Disponível em: http://bit. ly/36liQnn. Acesso em: 29 set. 2015.

40. INSTITUTO NACIONAL DE COLONIZAÇÃO E REFORMA AGRÁRIA. Instrução Normativa $n^{\circ} 57$, de 20 de outubro de 2009. Regulamenta o procedimento para identificação, reconhecimento, delimitação, demarcação, desintrusão, titulação e registro das terras ocupadas por remanescentes das comunidades dos quilombos de que tratam o Art. 68 do Ato das Disposições Constitucionais Transitórias da Constituição Federal de 1988 e o Decreto n ${ }^{\circ}$ 4.887, de 20 de novembro de 2003. Brasília, DF, 2009b. Disponível em: http://bit. ly/36mmwdz. Acesso em: 29 set. 2015.

41. LATOUR, Bruno. Ciência em ação: como seguir cientistas e engenheiros sociedade afora. São Paulo: Unesp, 2000.

42. LEITE, Ilka Boaventura (org.). Laudos periciais antropológicos em debate. Florianópolis: Nuer, 2005a.

43. LEITE, Ilka Boaventura (org.). Relatórios de peritos antropológicos em debate. Florianópolis: Nuer, 2005b.

44. L'ESTOILE, Benoit de; NEIBURG, Federico; SIGAUD, Lygia (org.). Antropologia, impérios e estados nacionais. Rio de Janeiro: Relume Dumará, 2002.

45. LIMA, Antonio Carlos de Souza. Os relatórios antropológicos de identificação de terras indígenas da Fundação Nacional do Índio: notas para o estudo da relação entre a antropologia e indigenismo no Brasil, 1968-1985. In: LIMA, Antonio Carlos de Souza; BARRETO FILHO, Henyo Trindade (org.). Antropologia e identificação. Os antropólogos e a definição de terras indígenas no Brasil, 1977-2002. Rio de Janeiro: Contra Capa, 2005. 
46. LIMA, Antonio Carlos de Souza. A Antropologia e o Estado no Brasil: breves notas acerca de uma relação complexa. In: FRANCH, Mónica; ANDRADE, Maristela; AMORIM, Lara (org.). Antropologia em novos campos de atuação: debates e tensões. João Pessoa: Mídia Gráfica Editora, 2015.

47. LIMA, Antonio Carlos de Souza; BARRETO FILHO, Henyo Trindade (org.). Antropologia e identificação: os antropólogos e a definição de terras indígenas no Brasil, 1977-2002. Rio de Janeiro: Contra Capa, 2005.

48. LITTLE, Paul. Territórios sociais e povos tradicionais no Brasil: por uma antropologia da territorialidade. Anuário Antropológico, Brasília, DF, v. 28, n. 1, p. 251-290, 2003.

49. MARCUS, George; CUSHMAN, Dick. Ethnographies as text. Annual Review of Anthropology, Palo Alto, v. 11, p. 25-69, 1982.

50. MINISTÉRIO DA CULTURA. Fundação Cultural Palmares. Portaria $\mathbf{n}^{\circ} \mathbf{4 0}$, de $\mathbf{1 3}$ de julho de 2000. Estabelece as normas que regerão os trabalhos para a identificação, reconhecimento, delimitação e demarcação das autodenominadas “Terras de Pretos", "Comunidades Negras", "Mocambos", "Quilombo", dentre outras denominações congêneres. Brasília, DF, 2000. Disponível em: http://bit. ly/2QjFCLD. Acesso em: 29 set. 2015.

51. MOURA, Margarida Maria. Camponeses. 2. ed. São Paulo: Ática, 1988.

52. NÚCLEO DE ESTUDOS SOBRE IDENTIDADE E RELAÇÕES INTERÉTNICAS. Territórios quilombolas: reconhecimento e titulação das terras. Florianópolis: UFSC, 2005. (Boletim Informativo do Nuer v. 2, n. 2).

53. NÚCLEO DE ESTUDOS SOBRE IDENTIDADE E RELAÇÕES INTERÉTNICAS. Quilombos no Sul do Brasil: perícias antropológicas. Florianópolis: UFSC, 2006. (Boletim informativo do Nuer v. 3, n. 3).

54. O’DWYER, Eliane Cantarino (org.). Quilombos: identidade étnica e territorialidade. Rio de Janeiro: Editora FGV, 2002.

55. O’DWYER, Eliane Cantarino (org.). O papel social do antropólogo: a aplicação do fazer antropológico e do conhecimento disciplinar nos debates públicos do Brasil contemporâneo. Rio de Janeiro: E-papers, 2010.

56. OLIVEIRA, João Pacheco de. Uma etnologia dos “índios misturados"? Situação colonial, territorialização e fluxos culturais. Mana: Rio de Janeiro, v. 4, n. 1, p. 47-77, 1998.

57. OLIVEIRA, Osvaldo Martins (org.). Direitos quilombolas e dever de Estado em 25 anos da Constituição Federal de 1988. Rio de Janeiro: ABA, 2016.

58. OLIVEIRA, Roberto Cardoso de. Identidade, etnia e estrutura social. São Paulo: Pioneira, 1976. 
59. PINHO, Osmundo Araújo. Introdução. In: SANSONE, Lívio; PINHO, Osmundo Araújo (org.). Raça: novas perspectivas antropológicas. Salvador: EDUFBA, 2008.

60. POLLAK, Michael. Memória e identidade social. Estudos Históricos, Rio de Janeiro, v. 5, n. 10, 1992.

61. QUEIROZ, Renato. Caipiras negros no Vale do Ribeira: um estudo de antropologia econômica. 1983. Dissertação (Mestrado em Antropologia) - Universidade de São Paulo, São Paulo, 1983.

62. REIS, Rosana Rocha. O direito a terra como um direito humano: a luta pela reforma agrária e o movimento de direitos humanos no Brasil. Lua Nova, São Paulo, n. 86, 2012.

63. RIOS, Flávia. O protesto negro no Brasil contemporâneo. Lua Nova, São Paulo, n. $85,2012$.

64. SANTOS, Carlos Alexandre Plínio dos. As comunidades negras rurais nas ciências sociais no Brasil: de Nina Rodrigues à era dos programas de pós-graduação em antropologia. Anuário Antropológico, Brasília, DF, v. 40, n. 1, p. 75-106, 2015.

65. SILVA, Dimas Salustiano da. Apontamentos para compreender a origem e propostas de regulamentação do Artigo 68 do ADCT 1988. In: NÚCLEO DE ESTUDOS DE IDENTIDADES E RELAÇÕES INTERÉTNICAS. Regulamentação de terras de negros no Brasil. Florianópolis: UFSC, 1997. (Boletim Informativo Nuer v. 1, n. 1).

66. VOGT, Carlos; FRY, Peter. Cafundó: a África no Brasil. Campinas: Ed. Unicamp, 1996.

67. WOORTMANN, Ellen. Parentesco e reprodução camponesa. Ciências Sociais Hoje, São Paulo, n. 85, p. 192-219, 1985.

68. WOORTMANN, Klass. Com parente não se neguceia: o campesinato como ordem moral. Brasília, DF: Tempo Brasileiro, 1990. 